\title{
LINGUISTIC EMBODIMENT OF EMOTIONS IN PETER MAYLE'S NOVEL "HOTEL PASTIS"
}

\section{Natalya Romanova ${ }^{1}$}

DOI: https://doi.org/10.30525/978-9934-588-15-0-113

Abstract. The article suggests the research of emotions in the German linguoculture. The relevance of choosing a topic is determined by the anthropocentric orientation of modern linguistics and the fragmentarity of special scientific papers. The etymology of the key term was covered, the specificity of "new images" of empirical material was considered, the lexical features of verbalization of the phenomenon were described, and the classification of emotions by sign was presented. The subject of the research is the paradigm of emotions of the post-modern literary text, which was translated from English into German in 2003 by a group of translators. The foundations of the methodological basis of the research are the linguistics of emotions, which integrates the ideas and achievements of the modern psychology of emotions (C. E. Izard), psycholinguistics, lexical semantics, communicative linguistics and text emotiology. A number of general scientific and linguistic methods, namely hypothetical-deductive, logical-semantic, semantic, contextual, interpretative-textual, descriptive method, were used during the research. The aim of the article is to analyze the corpus of emotions in Peter Mail's novel "Hotel Pastis". The outlined aim led to the solution of specific tasks, including the identification of the lexical embodiment of emotions, defining the paradigm of emotions and their classification by the qualitative characteristic of the individual's attitude to the effects that they experience through their needs, interests, states of mind. It is proved that the personality's emotional potential is subjective, intimate, open, changeable, combining the real and the ideal. The real is based on a certain intimate experience, the ideal appeals to the image of a certain emotion. It was found that the emotions of the post-modern translated literature are multifaceted and distinctive. It was

${ }^{1}$ Doctor of Philological Sciences, Associate Professor,

Professor of the Department of German and Romanic Philology

Kherson State University, Ukraine 
revealed that the notion "emotion" comes from the French term, taking into account the nature of the inner (spiritual and mental) world of a person, formation of which correlates with the surrounding and imaginary world, differentiated within the national tradition (French, German, American). Representative experiences were systematized through the classification of emotions and manifested through positive, negative, neutral, indeterminate, imaginary and combined (emotional patterns) emotions. Negative emotions with their variants and combined emotions are dominating. Among the negative emotions, the emotion of contempt and the emotion of emptiness are the "strongest". The mediators of these emotions are anger as a variant of the emotion of rage and depression as for the emotion of grief. The leading emotion of the emotional pattern is joy. The position of the emotion of joy within the emotional pattern is dual: it precedes another emotion (surprise, interest, grief, fear) or is their consequence (surprise, fear, disgust, grief, unagitation), the semantics is grading: from minimal value to neutral, morphological, comparative, maximal one. The emergence of emotions and their variants is determined implicitly by the type of subject or communicative situation. Lexical means of realization of emotions and their variants are traditional: a word, a free word-group/a constant collocation, a cliché; compositional speech forms of realization of emotions and their variants are static: speech (monological, dialogical, polylogical) and description (a report on somatic and physiological changes in the human organism).

\section{Introduction}

Analyzing emotions in fiction, researchers emphasize their ambiguity, complexity, variability, diversity $[9 ; 11 ; 14 ; 17]$. Such a broad characteristic of the phenomenon can be explained, on the one hand, by the specificity of the personality's transcoding psychological information into spiritual one, on the other hand, by the combination of different worldviews: scientific and aesthetic, mediated by the experiences, emotions, author's feelings [8]. Psychological information is a collection of knowledge about the psyche of a human or a superior being [7, p. 147], spiritual one is about a positive moral and ethical "exemplary" state of linguistic community development [7, p. 48]. These varieties of knowledge should not only correspond to the knowledge of the linguistic kind [6, p. 65], but also go beyond their 
limits, that is, satisfy the cultural needs and interests of the author and the addressee of a certain chronological dimension. With regard to worldview, its interpretation in the linguistic sphere appeals to the system of "views of life, nature and society", "understanding the world", views, beliefs and the conception [4, p. 254]. Scientific worldview synthesizes proper authentic knowledge about a certain branch of a person's commercial activity, in particular about emotions of the mental category, aesthetic worldview covers pre-scientific, scientific and encyclopedic knowledge about the outer world, examines all this knowledge through the prism of aesthetic evaluation with the scale "good - not good" and transforms them into the writer's aesthetic ideal which is embodied in the work of fiction. The reconstruction of emotions in fiction is relevant, because it enables not only getting involved in the emotional sphere of the author and their characters, but also highlighting their most important thoughts about the emotiogenic situation.

The aim of our scientific exploration is to analyze the corpus of emotions in Peter Mail's novel "Hotel Pastis", translated into German (2003).

The research objectives consist in identifying the lexical embodiment of emotions, defining their paradigm and classifying by sign of emotion.

The methodological basis of the research is built on the linguistics of emotions, which integrates the ideas and achievements of the psychology of emotions (C. E. Izard), psycholinguistics (V. von Humboldt, O. O. Zalievska, O. O. Potebnia), lexical semantics (Yu. D. Apresian, M. V. Hamziuk, N. V. Romanova), communicative linguistics (F. S. Batsevych, H. I. Prykhodko, V. I. Shakhovskyi) and text emotiology (O. E. Filimonova, V. I. Shakhovskyi). A number of general scientific and special linguistic methods with a set of research techniques such as the hypothetical-deductive, logical-semantic, semantic, contextual, interpretativetextual, and descriptive method, were used during the research.

\section{The notion of "emotion" in the German linguoculture}

The interpretation of the notion "emotion" depends on the methodology and the subject of the research [10, p. 88], as well as on national scientific traditions [2, p. 17].

In the modern German language, there are two lexical items to indicate emotions: Emotion and Gefühl. The word Emotion was borrowed in the middle of the seventeenth century from the French language as a philosophi- 
cal term by R. Descartes, who differentiated the passions and emotions of a person [12, p. 4; 13, p. 11-12], Gefühl is the result of the word-formation of the ethnicity's puristic activity.

It should be emphasized, that over the course of 4.5 centuries, the analyzed elements have been determinologized and become common linguistic units with basic and derivative meaning. In particular, the derivative of feminine gender Emotion has the homogeneous meaning of "Gefühlsregung (emotion), Gemütsbewegung (emotional experience, emotion), Erregung (agitation, excitement)", derivative of neuter gender Gefühl is heterogeneous, detailed in three planes: physical "1 Wahrnehmung durch den Tastsinn (touch)", psychic "2 innere Regung, seelische Empfindung (emotion, feeling)", cognitive "3 Ahnung, ungenaues Wissen (preperception, inaccurate knowledge)" [20, p. 297, 398; 3, p. 266, 274, 217, 34, 711].

According to the above definitions, the most important feature of an emotion is movement. We formally distinguish such varieties of movement as: psychological (Gemütsbewegung), psychic (Gefühlsregung, Erregung, innere Regung, seelische Empfindung), physical (Wahrnehmung durch den Tastsinn), and mental (Ahnung, ungenaues Wissen). The psychological movement is closely related to the spiritual and sensual life of a person (Gemüt), the psychic movement is identical to the displacement of emotional energy within a living organism (Gefühl, innere, seelische), the physical movement is equivalent to a contact of the upper extremities (fingers) with objects of the outside world (Tastsinn), the mental movement is an element of the peripheral part of the conceptual sphere, which is open and serves as a source of forming new concepts (ungenaues). Each of these types of movement is accompanied by a certain type of evaluation: psychological movement is correlated with the affective evaluation (scale "good - bad"), psychic - with emotional evaluation (scale "positive - negative"), physical - with modular evaluation (scale "pleasant - unpleasant"), mental - with utilitarian one (scale "approvingly - disapprovingly"). Thus, we can conclude that the notion of "emotion" is relatively new (mid-XVII century), alien (the French mentality), multicultural (France, Germany), polyconceptual within the framework of philosophical scientific knowledge (according to R. Descartes, emotion is a spiritual phenomenon, according to G. V. Leibnitz - intellectual one), multifunctional (philosophical term, common word), monosemic (psychological category) and at the same time polysemic (physical, psychic, cognitive categories). 


\section{Specificity of the images in P. Mail's novel "Hotel Pastis"}

Observation of the factual content shows [19] that the topic of emotions is not a goal in itself. It serves rather as a background for illuminating the intimate relations of the industrial and domestic spheres, a mechanism of internal changes in the personality of another (German, Arab) culture and the intercultural harmonization of feelings, emotional experiences of the main characters in the novel - an Englishman, Simon Shaw, and a French woman, named Nicole Bouvier, and at the same time it puts emphasis on the image of a "new English woman" - an emancipated woman who rules over her husband, is strong-willed, ironic, aggressive, jealous (Caroline Shaw). The image of a "new man" who represents "his" ethnicity is also added here. It is a "positive image" of an Englishman and a "negative image" of a Frenchman.

The "Englishman" makes a brilliant career (Ernest), becomes an integral part of his boss's family, runs his household gladly, always has the "perfect" look (Ern), is interested in fashion, is an aesthete, a gourmet, sociable, sincere, easily adaptable to the environment (Ernie). However, it is impossible to call him a "gentleman" because he is impulsive, likes alcohol, neglects a woman as a biological and social being, is ironic, and ultimately, has no sophisticated manners.

The "Frenchman" is a man with a criminal background, loyal to his friendship, but indifferent to his family and loved ones. This image is complicated by childlessness, deviant behavior, unsanitary living conditions, personal hygiene, more precisely, its absence, unhealthy nutrition, "voluntary unemployment".

The Frenchman resembles a "big child" who believes in miracles, "easy money" - he plays the lottery, has no complexes in his appearance, manner of speech or behaviour, he is not depressed by the remorse (Jojo). The coincidence of the notions of "childhood" and "justice" is obvious. In a civilized country, as far as is known, a child is not punished but protected, looked after, and loved.

The "child" has a "father", a "mentor", an "advisor", who is known in the antisocial circles as the "big man" under the name General. The child dreams of praise, so he devises a bold plan to attack a bank in a neighboring town, shares this idea with his "father" and successfully puts it into action. Thus, a "child" "becomes adult", "grows up", goes as high as the status of a "father", becomes a qualitative measure of the relationship between 
"rich" and "poor", "clever" and "foolish", "ambitious" and "unambitious", "active" and "passive", a "leading role" and a "secondary one".

Despite their polarity, the images of "new ethnic men" share a common trait - a love of adrenaline. This love inspires actions that have different consequences. For example, Ernest makes his way from a car mechanic to a manager of a hotel "Pastis", Jojo becomes a millionaire in a straw hat, a new t-shirt with a Vivent les Vacances! printing on the front! (Long live the holidays!), blue jeans, and with a backpack stuffed with the money, stolen and "earned" through the sale of a hostage - a foreign (American) schoolboy. In the foreground, there is a "new feature" of the "new Frenchman" - combining, resonating, layering, mixing the "renewed existence" through aesthetics, economics, (ethno)psychology, technological progress, philosophy and biology. With his partners in crime (eight people), Jojo goes to Spain by a comfortable "archaic (running on diesel) orange-brown tourist bus. He considers Spain to be a symbol of freedom of travelling by air, as a centre of vertical-horizontal orientation, as a starting point for material connection with the ideal/heavenly world Und vom Flughafen in Madrid konnte man überall hinkommen [19, p. 434].

Colours become symbolic too: the blue colour represents sacredness and power, the orange colour directs to the unreligious things and force of nature (fire), the brown colour actualizes social and antisocial, psychological and biological, ethical and cultural [18, p. 191-192, 146, 157-158]. A similar contrast is the highlight of the whole novel. The author contrasts irony and seriousness, hatred and love, aesthetics and ugliness, disrespect for a human and admiration for nature, intelligence and stupidity, lifestyles of rural and urban residents, law and crime, reality and irreality, etc. This contrasting effect "sheds light" on the writer's work, brings the author closer to the reader, makes them part of the general world, encourages the addressee to question artistic values in different cultural systems (English, French, American).

Due to the volume of the article, we do not suggest the study of these oppositions. They may be a prospect for future research.

\section{Lexical features of the verbalization of emotions}

It is proved that not only the cognitive activity of a person (R. O. Budahov, V. V. Vynohradov), but also its emotional potential (N. V. Romanova, P. A. Selihei) is depicted in the vocabulary. We distinguish the diversity of 
the vocabulary layers, including the affective vocabulary that nominates emotions and their variants (Ärgerliche, staunend, verabscheuen), the emotional vocabulary expresses emotions and their variants (dürr, todschick, bombardieren), the stylistically coloured vocabulary demonstrates functional yield of emotions and their variants (dreckstarrend, Scheiß, Scheißho$t e l)$, the foreign language vocabulary extends the original emotions and their variants or "enriches" (the French language) ("Zu Beginn eine salade tiede, dachte ich mir, mit ein paar Streifen foie gras, und dann Ihr Leibgericht." [19, p. 21], (the English language) ("LET'S ... GET IT ON ... OOOOOOOH, LET'S GET IT ON..." [19, p. 107]); at the same time, it is appropriate to point out that foreign language elements (French) are grouped in "Glossar" in alphabetical order and italicized [19, p. 451-463]; English characters are represented by spelling: capital letters "COME ON COME ON COME ON...", lowercase letters okay, capital letters + lowercase letters Rubber House, orthography Scotch Whisky, Mr. Ziegler, type - italics Horse and Hound), the synsemantic vocabulary adds and deepens the meaning of emotions and their variants (Sie wiederum haßte ihn, weil sie ihn nicht loswerden konnte [19, p. 11]), free word-groups/constant collocations with affective meaning expressively colour and individualize emotions and their variants (die Nase rümpfen, Ahs und Ohs hauchen, unter seine Fittiche nehmen), affective clichés condense the culture of emotions (armer Liebling, mein Lieber, meine Liebe), diminutives (emotionally) evaluate the outside world (Schmuckkästchen, Kerlchen, Päckchen), kinesives describe the physiology of emotions and their variants (Ernest warf einen Blick auf einen Notizblock neben dem Telefon, Mit hochgezogenen Augenbrauen und leicht geschürzten Lippen nahm Ernest den Hörer ab [19, p. 13]), affectives reflect emotions and their variants ("Was hat sie gesagt?" / "Ach, nur das übliche Heulen und Zähneknirschen.” [19, p. 15], "Ich werde sehen, ob Mr. Wilkinson abkömmlich ist." / Du lieber Himmel. Zuerst eine taube Nuß am Telefon, und jetzt war er auch noch gezwungen, sich Ravels Bolero anzuhören, bis sich Wilkinson entschieden hatte, ob er nun abkömmlich war oder nicht [19, p. 17] (hereinafter graphic selection emphasized by the author. - N. R.), connotatives synthesize emotions and logical and subject meaning ("Wie ich sehe, fühlen wir uns heute abend als Bohemien. Als richtiger Streuner, stimmt's?” [19, p. 24]), occasionalisms represent the emotional potential of speakers (Scheißkerl, Gummibaron(e), Werbe- 
texter, Latex-Bestellungen, Hintergrundinformationen, Präsentationsmappe), anomalies simulate emotions and their variants (Guten-Morgen-Gruß, Cash-flow-Probleme, Joghurt-Kundschaft, Agentur-Kunden-Verhältnis, Gault-Millau-Restorantführer, Full-time-Job), shortenings of a) compound words (complete: "Das ist Ihr Markt, Kino und MTV. Und alles andere knüpft daran an - Polster, Produktplazierung, Radio, T-Shirts - können wir jetzt bitte die Dias sehen, Terry?" [19, p. 108]; incomplete: Kfz-Werkstat, JFK-Flughafen), b) archaisms (Schampus from Champagner), c) borrowed words (Pulli from English Pullover) deform emotions, proper names that indicate the emotional feature of the name bearer (Jojo) or the emotional behavior of the latter (Ern=Ernest "seriousness" [21, p. 155-156; 3, p. 217]) identify emotions and their variants.

The above examples illustrate that human emotions perform certain functions, such as the evaluation function, the signal function, the regulatory function, the stimulation function. Among these functions, the function of evaluation is basic, because it allows a person not only to highlight the essential and important for the nomination of an object, phenomenon, event, but also to adapt the nomination to "their" or "alien" norm, to create new values, to organize cognitive or spiritual activities, to qualify "their" and "alien" linguistic knowledge, to analyze objective and subjective linguistic experience, to differentiate between "successful" and "unsuccessful" ways of existence, etc.

The studied emotions can be qualified by the sign: positive, negative, neutral, indeterminate, imaginary, combined. Positive emotions are relevant to the positive attitude of the author or their characters to objects, events, phenomena, situations of objective or imaginary reality, negative emotions are antonymic to positive emotions, indeterminate emotions represent "blurred" or undefined attitude of the subject to the outside (real or irreal) world, imaginary or potential emotions appear as a result of forming conditional connections within the emotiogenic situation, combined emotions are identical to the emotional patterns, which are understood as the combination of two or more "basic emotions, which, in certain conditions, are unfolding simultaneously or in a certain sequence, and which interact with each other" through "motivational impact on the individual and his behaviour" [1, p. 69].

In the focus of the theory of differential emotions (C. E. Izard), positive emotions are the emotion of interest, the emotion of joy, the emotion of 
surprise, the emotion of shame, the emotion of guilt; the negative ones are: the emotion of grief, the emotion of rage, the emotion of disgust, the emotion of contempt, the emotion of fear - these are all ten basic emotions [1, p. 20, 55].

It should be noted that the empirical register of emotions and the theoretical one do not coincide. We see the difference in the nature of the phenomenon. It is about basic and secondary emotions. Secondary emotions are derived from basic emotions, thought of as social, cultural and artistic. In a broad sense, social emotions are the psychological response of a person to the outside world, cultural emotions are the social and psychological reaction to the culture of ethnicity, artistic emotions are the spiritual reception to the image of the outer world. The image of the outside world is defined, according to N. P. Tropina, as "a reflection of the basic cultural constants, social stereotypes, cognitive schemes, elements of the CPW in the collective consciousness and in the collective unconsciousness of the ethnos" [15, p. 223-224]. We think that the abbreviation CPW denotes a conceptual (notional) picture of the world, which is interpreted as a set of scientific and non-scientific (pre-scientific, "naive") knowledge of humanity about the outer world [5, p. 110-120]. We do not aim here to find a dividing line between basic and secondary emotions, as well as between the author's emotions and the characters' emotions. The classification given below is conditional and open-ended, as it is based on an integrated approach that enables us to comprehend and combine different scientific views on emotions in a literary text.

\section{The classification of emotions by sign}

\subsection{Positive emotions and their variants}

With the help of the selection method, about 15 positive emotions and their variants were recorded during the research: 1) surprise Carolines Freundinnen - diese dürren, todschicken Freundinnen, die sich ausschließlich von Salat und einen gelegentlichen verruchten Glas trockenen Weißweins ernährten - hatten angesichts des Hauses staunend ihre Ahs und Ohs gehaucht [19, p. 10]; 2) apology Sie entschuldigen bitte, dass ich so frank du frei sage, aber die City ist im Moment ein wenig beunruhigt, was den Werbesektor betrifft [19, p. 18]; 3) joy Die Scheidung bekam 
Ernest offensichtlich ausgezeichnet; er war sichtlich fröhlicher, seit Caroline das Haus verlassen hatte [19, p. 21]; 4) amusement "Lehnen Sie sich zurück und genießen Sie es. Dazu sind Versuchungen da.” [19, p. 28]; 5) compassion Der General zeigte Mitgefühl, ein Mitgefühl, das vor allem Erleichterung darüber war, daß es anderen noch schlechter ging als einem selbst [19, p. 31]; 6) trust Da Jordan eine Enthüllung vermutete, beugte er sich vor, und Simons Tonfall wurde vertraulich [19, p. 43]; 7) friendship Sie hatten sich kennengelernt, als Simon die Aktienmehrheit von Murats Agentur erworben hatte, und die Geschäftsverbindung hatte sich zu einer Freundschaft gewandelt [19, p. 48]; 8) delight Seine Augen sprühten vor Begeisterung, was teilweise auf die zuvor eilig in der Toilette geschnupft Prise Kokain zurückzuführen war [19, p. 103]; 9) satisfaction 9.1 metaphorical Immer wieder wurde Gelächter laut; dies war ein Ort des Vergnügens [19, c. 50]; 9.2 natural ("Doch so angenehm es im Tresorraum auch sein mag, wir müssen ihn verlassen." [19, p. 58]; 9.3 social Und zwischen den Bissen eine Lektion in diesem speziellen Akzent - teils Französisch, teils unverständliches Zeug, unterbrochen von dem bellenden Gelächter Mamans und dem Kichern des Mädchens, die offensichtlich Vergnügen fanden an den verzweifelten Versuchen Simons, den polternden und genäselten Lauten der immer schneller werdenden Reden Bonettos zu folgen [19, p. 75]; 9.4 psychic Sie schob ihr Haar zurück und spürte, wie eine angenehme Erregung sie durchströmte [19, p. 131]; 10) interest Simon bestellte bei dem Mädchen, das Nicoles Kleid mit unverhohlenem Interesse musterte, Getränke [19, p. 92]; 11) gratitude Da eilte einer von den Werbeleuten mit vor der Brust baumelnder Sonnenbrille auf Simon zu. / "Alles klar, wir haben sie gefunden." / Simons Kopfschmerzen ließen ein wenig nach. "Na, Gott sei Dank. Wo ist sie?” / "Unter diesem großen Tisch im Restaurant." [19, p. 324]; 12) relief Ein junges Pärchen, das in der Dunkelheit zu der von der place herübertönenden Musik tanzte, eilte in den Schutz des Lichtes davon, als es die sieben Männer auf sich zukommen sah. / "Voilà", meinte Jojo erleichtert. "Da ist er, wie er gesagt hat.” [19, p. 374]; 13) hope Hoffnungsvoll blickte er in die Runde, auf der Suche nach einem Anzeichen, daß sie ihn verstanden [19, p. 392]; 14) love Jetzt kam das, was er am meisten liebte, der künstlerische Teil sozusagen, nämlich die Dosis exakt so zu bestimmen, daß nicht gleich das ganze Haus über ihnen zusammenstürzte [19, p. 377]. 


\subsection{Negative emotions and their variants}

Negative emotions and their variants occur relatively more often than positive ones - in general there are 20 registers of them: 1) contempt Doch sobald sie allein waren, stieß sie zwischen schmalen Lippen stichelnde Bemerkungen über seine Abwesenheit hervor, über seine Müdigkeit, sein Aufgehen in der Arbeit, die Vernachlässigung - ja, es gab kein anderes Wort dafür: die Vernachlässigung ihrer Person [19, p. 10]; 2) hatred Ernest mißbilligte ihre Verschwendungssucht, ihre gesellschaftlichen Ambitionen und ihre absolut mangelhaften Fähigkeiten als Hausfrau. Sie wiederum haßte ihn, weil sie ihn nicht loswerden konnte [19, p. 11]; 3) rage Wilkinson Tonfall wurde reserviert, und mit jeder Herablassung, mit der Männer von Fach einem Streit aus dem Weg zu gehen pflegen, sagte er: "Ich bin davon überzeugt, daß man in der City durchaus etwas von der Werbebranche versteht. Mehr Besonnenheit und weniger Wunschdenken wären also angebracht." / "So eine Scheiße!' Simon knallte den Hörer auf die Gabel, dabei fiel Zigarrenasche auf seine Hose [19, p. 19]; 4) disgust "Eng und aus Plastik. Genau das Richtigste für einen Zwerg ohne jeden Geschmack, der Kochen zutiefst verabscheut. Die Maklerin war ungeheuer stolz darauf [19, p. 26]; 5) boredom "Ich kenne Sie. Alle fünf Minuten unterwegs nach Neu York oder Paris oder Düsseldorf. Immer nur in Eile, Probleme mit der Zeitumstellung und schlechte Laune. Und wenn Sie in London sind, jagt eine langweilige Sitzung sie nächste.” [19, p. 26]; 6) fear Simon sah das Erschrecken auf den Gesichtern der Frauen, als die mehrere tausend Dollar teuren Chinchillas beiläufig von einem Ober eingesammelt und auf das Garderobenregal hinter ihrem Tisch geworfen wurden [19, p. 48]; 7) guilt Willkommen in England. Sie schauderte und fühlte sich grundlos schuldig. In Frankreich hätte sie den Mund aufgemacht und eine Erklärung verlangt; doch hier, als Fremde, noch dazu mit ihrem Englisch, war sie zu unsicher, um sich bei dem Mann mit dem grobschlächtigen roten Gesicht und dem feindseligen Blick zu beschweren [19, p. 127]; 8) grief Sie schwieg, das Kinn auf eine Hand gestützt, und sah ihn prüfend an - ein müdes Gesicht, dachte sie, mit zerfurchter Stirn und einem Anflug von Grau in einer Augenbraue - und traurig [19, p. 139]; 9) anger Als er Crouchs Stimme hörte, blickte sich Simon, der an der Bar stand, um, erkannte das bösartige Gesicht und wandte sich wieder seinem Glas zu [19, p. 339]; 10) depression Der Rauch aus seiner Zigarette kräuselte sich, und Enrico saß starr 
und unbeweglich da [19, p. 353]; 11) hysterics "Ich habe es aufgegeben, ernst zu sein. Ich habe einen geistesgestörten Onkel, der mich ständig um Taschengeld anpumpt, nebenan wohnt eine hysterische alte Dame, deren Mann Tag und Nacht auf der Leiter steht, und jetzt will mein neuer Freund Enrico das Hotel in ein Jagdrevier für die Mafia umwandeln." [19, p. 356]; 12) loneliness Ist es dir noch nicht aufgefallen, daß wir kaum noch einmal allein sind? [19, p. 357]; 13) shock Der Schock des kalten Wassers zwischen den Beinen, glitschige, kantige Steine unter den Füßen, dann der Sprung in die Schwärze des Kanals [19, p. 376]; 14) doubt Das Adrenalin war verbraucht, und nun machte sich Ungeduld breit - und diese schleichenden Zweifel, die nicht weichen wollten [19, p. 385]; 15) physical pain Knirschendes Metall, als ein Pedal an einer Tür entlangschrammte, ein Fluch des Schmerzes, als einer vor Panik zu schnell aufsprang und sich die Spitze des Sattels in die Hoden rammte, hektisches Gefummle, als sie versuchten, die Füße in die Rennhaken zu schieben [19, p. 387-388]; 16) tension Vor Spannung zitternd, quetschten sie sich in der Ecke zusammen; ein banges Schaudern durchfuhr sie wie eine kalte Brise [19, p. 387]; 17) disappointment Aber er kam nicht, und als Ernest ihr sagte wie hübsch sie aussehe, zuckte sie nur enttäuscht die Achseln [19, p. 395]; 18) tiredness Er schwebte wie af Wolken vor Müdigkeit, konnte aber nicht schlafen und spürte, daß er immer reizbarer wurde [19, p. 409]; 19) danger Der General stand da und beobachtete, wie der große Wagen losfuhr, und mit dem Verschwinden der unmittelbaren Bedrohung, die Enrico verkörperte, wichen Angst und Schrecken, und Wut stieg in ihm auf [19, p. 420]; 20) emptiness Doch ihm war schwindelig vor nervöser Erschöpfung, und er spürte eine plötzliche Leere in sich [19, p. 431].

\subsection{Neutral emotions}

Neutral emotions, represented by calmness that corresponds to a state of "psychophysiological and mental equilibrium" [16, p. 201-202], are the least presentable in the revealed paradigm Jojos Herz beruhigte sich wieder, als er ausatmete und die Schultern locker ließ [19, p. 375].

\subsection{Indeterminate emotions}

Indeterminate emotions deny a certain experience through the prism of evaluation without being an antonym, for example, unsurprise Sein Le- 
ben bestand darin, Menschen in geschlossenen Räumen gegenüberzusitzen, Angestellte zu hätscheln, Kunden zu schmeicheln, die Wilkinson und Vorstandssitzungen und Wirtschaftsjournalisten zu ertragen. Eigentlich kein Wunder, daß Caroline das nicht hatte mitmachen wollen [19, p. 19-20].

The emotion of unsurprise is marked by the word combination kein Wunder, the primal semantics of which is conditioned by the lack of both curiosity and the woman's desire to share the professional interests of the man. It is experimentally proved that the occurrence of a certain emotion is determined by external or internal factors. External factors activating the emotion of surprise include: an unexpected, sudden event - a thunderstorm, fireworks flash or a sudden appearance of a friend; internal activators are associated with the individual's memories of the corresponding emotiogenic situation [1, p. 190, 192].

The above external and internal factors do not actually have anything in common with the investigated emotiogenic situation. With certain reservations, it can be assumed that the emotion of unsurprise characterizes a high degree of emotional resistance to the emotional stimuli or indicates apathy as one of the psychological characteristics of an emancipated woman.

The emotion of ungrief is interpreted due to the divorce of spouses "Auf fröhliche Zeiten, mein Lieber. Sie bedauern es nicht, hier wegzugehen, oder? Sie haben sich hier doch nie so recht zu Hause gefühlt." [19, p. 22]. The reason for divorce is banal - "different views of life". Such an interpretation shows that there was no real love between a man and a woman, there was a workplace romance, a passion that temporarily colored the lovers' "gray life". The subject of passion for the woman was a status, and in the case of the man it was for sex. Both the woman and the man fell into the gravity field of the leading materialistic need. Having got what they wanted, they got bored and sought new experiences, new "favourite things". The complete elimination of the impediment from the emotional process is erroneous and illusory, since the formal dissolution of intimate relationships does not guarantee the education, formation and development of true feelings.

In general, this kind of emotions comprises eight positions: shamelessness, the emotion of unsurprise, the emotion of unjoy, the emotion of disinterest, the emotion of distrust, emotion of ungrief, the emotion of unfear, the emotion of angerlessness. There are obvious shifts in the emotional sphere of the personality on gender and quantitative traits. The "new (emancipat- 
ed) woman" understands the emotions of shame, joy and grief deeper than the "new man", and the "new man" knows about the emotions of interest and rage better than the "new woman". The quantitative trait is applied only to a man, his multiplicity, and implies a deeper awareness of the emotions of fear and faith.

\subsection{Conditional emotions and their variants}

The sign of conditional emotions and their variants intersects with the sign of direct emotions, in particular, positive ones 1) interest " $\mathrm{Ja}$, das würde mir gefallen. Die Henkersmahlzeit. Was würden Sie gern essen?" / "Ich habe noch schnell eine Flasche von dem dreiundsiebziger Petrus aus dem Keller geholt, bevor das auch noch alles verschwindet. Etwas, was dazu paßt." [19, p. 16]; 2) joy "Ich habe eine copine - eine Freundin in London aus früheren Zeiten. Sie hat mich schon so oft eingeladen. Da könnte ich doch dein Auto mitbringen? Das wäre doch lustig, oder?" [19, p. 116-117]; 3) surprise "Ich war bei Bruno am Beauchamp Placeein richtiger Goldschatz und schrecklich indiskret. Weißt du, sie sehen all die Narben vom Gesichtsliften, diese Friseure. Du wärst erstaunt, wenn du wüßtest, wer alles welche hat. Aber komm doch erst mal rein. " [19, p. 129130]; 4) satisfaction Es wäre ihm ein großes Vergnügen, sagte er, Monsieur behilflich zu sein, falls er jemals ein Problem mit dem Hotel hätte, das zu dringlich oder zu delikat sei, um es der Polizei zu überlassen [19, p. 323]; 5) friendship Und viertes ... na ja, ich habe das Gefühl, wir würden gut miteinander auskommen [19, p. 446]; negative ones 1) rage Die Telefonistin hörte sich gelangweilt und ärgerlich an, als ob man sie beim Lackieren der Fingernägel und der Lektüre der Cosmopolitan gestört hätte [19, p. 17]; 2) guilt Nicole versuchte, eine schuldbewußte Miene aufzusetzen [19, p. 131]; 3) despair Er hatte vorgeschlagen, zuerst den Swimmingpool fertigzustellen, bevor man mit den Arbeiten am Haus begann. Auf diese Weise könnte man zu Beginn des Frühjahrs bereits mit der Gartengestaltung anfangen. Das war vernünftig, obwohl Simon sicher enttäuscht würde, wenn das Gebäude zu Weihnachten so unfertig wie zuvor war [19, p. 217-218]; 4) disgust "Und was ist mit Crouch?" / Nicole verzog das Gesicht, im Zwielicht sah es aus, als ob sie einen unangenehmen Geruch wahrgenommen hätte [19, p. 232]; 5) agitation Lächelnd zog sie eine Schulter hoch, und Simon fragte sich, wie lange es dauern würde, bis sie unter den Kellnern für Unru- 
he sorgte [19, p. 312]; 6) disappointment Der General gab sich alle Mühe, so zu tun, als sei er enttäuscht [19, p. 419]; 7) sadness Es wäre ausgesprochen traurig, wenn die Polizei die Namen auf diesen wunderbaren neuen Pässen suchen würde [19, p. 419] and neutral ones calmness Mathilde würde sich schon wieder beruhigen. Das hatte sie immer getan [19, p. 385].

\subsection{Combined emotions and their variants}

Positive or/and negative emotions can be combined to form emotional patterns. Theoretically, their minimum number, as already mentioned, is equal to two emotions, the maximum one - to three emotions [1, p. 69, 411, $208,265,266]$, in fact, we also find emotional patterns with four emotions, including indeterminate and imaginary ones (see examples further). The combinations of two emotions appeal to the so-called "standard" patterns and their variants:1) surprise + joy Simon war überrascht, wie viel er verstand. Es war schon lange her, mehr als zwanzig Jahre, daß er sechs Monate als Kellner in Nizza gearbeitet hatte. Damals hatte er fließend Französisch gesprochen, oder zumindest gut genug, um sich seinen Lebensunterhalt zu verdienen, und er war froh, daß etwas davon hängengeblieben war [19, p. 46]; 2) joy + surprise In dem dunkelbraunen Wollkostüm kam ihr Haar, das von einem helleren Braun war, besser zur Geltung, und die Farbe ihrer Seidenbluse nahm das Hellblau ihrer Augen wieder auf. Simon stellte sich vor, daß sie wahrscheinlich einen anstrengenden Vormittag hinter sich hatte: zuerst die Qual der Wahl bei den Kleidern für den Lunch im San Lorenzo um drei, und dann noch ein längerer Friseurtermin. Zu seiner freudigen Überraschung stellte er fest, daß er sie überhaupt nicht mehr attraktiv fand [19, c. 111-112]; 3) grief + joy Mit einem wehmütigen Lächeln sah er auf die Armbanduhr und gab ein Zeichnen, daß er zahlen wollte [19, p. 93]; 4) interest + joy "Ich muß jedoch sagen, daß Ihr Auftrag für uns besonders großem Interesse ist." / Simon machte eine Pause und lächelte sieben ausdruckslose Gesichter an [19, p. 101]; 5) tension + hostility Sie sahen einander schweigend an. Carolines Miene war angespannt und feindselig [19, p. 114]; 6) joy + affliction/grief Simon hatte sich offenbar gefreut, von ihr zu hören. Schade, daß er nicht kommen konnte. In ihren Gedanken formte sich eine Idee, doch alles hing von einer Frage ab: Hatte er es wirklich ernst gemeint, als er sagte, er habe die Nase voll vom Werbgeschäft? Bei den Engländern konnte man ja nie wissen. Sie lachten und weinten gleich- 
zeitig [19, p. 117]; 7) joy + interest Ein entschiedenes Nein wäre in den meisten Fällen wenigstes besser als dieses endlos zähe Wiederkäuen; dann wären wenigstens die Sitzungen kürzer. Aber er lächelte und nickte, gab sich interessiert und sagte "selbstverständlich», als ihm der oberste Gummibaron mitteilte, der Ausschuß müsse sich zurückziehen und die Vorschläge der Agentur in allen Einzelheiten diskutiere; die durchaus interessanten Vorschläge machten weitere Sitzungen im Rubber House nötig, bevor man eine Entschuldigung von solcher Tragweite treffe, und, ja...also [19, p. 110]; 8) joy + fear Sie fand es etwas seltsam, daß sie sich so sehr darauf freute, ihn wiederzusehen. Als sie eine Berührung am Fußknöchel spürte, zuckte sie zusammen. Doch es war nur eine streunende Dorfkatze, die schnurrend und mit wie zum Gruß erhobenen Schwanz an ihr vorbeistrich [19, p. 118]; 9) fear + joy Es war rührend zu sehen, wie die Freude wieder in Ernests Gesicht zurückkehrte. Es hellte sich förmlich auf, und er seufzte lang und tief. Keine Spur mehr von Niedergeschlagenheit. Dann zwinkerte er mehrmals sehr schnell mit den Augenlidern und blies laut vernehmlich durch die Nase. "Nun", sagte er schließlich. "Ich glaube, ich nehme einen Sherry, wenn ich darf." [19, p. 192]; 10) disgust + joy Simon brachte die Gläser und reichte eines davon Ern. "Sind Sie ganz sicher, daß Sie es machen wollen? Wirklich sicher?" "Was sollte ich denn tun, wenn Sie die Agentur verlassen? Den Chefhandlanger für seine Lordschaft Mr. Jordan spielen? Können Sie sich etwas Scheußliches vorstellen? Und ganz abgesehen davon: Das verspricht Spaß zu machen wie in den alten Tagen. Etwas Neues anfangen. Und Sie denken genauso, da bin ich sicher.” [19, p. 195]; 11) unagitaton + joy "Mach dir keine Sorgen. Sie wird sich vielleicht beschweren, aber er sicher nicht. Es macht ihm mehr Spaß, als seine Rosen zu gießen." [19, p. 305]; 12) imaginary relief + panic Harpers $(+$ a character similar to the Arabic script that cannot be technically rendered. N. P.) Queen fiel vor Erleichterung beinahe in Ohnmacht, doch kurz darauf geriet sie erneut in Panik [19, p. 324]; 13) imaginary disappointment + interest Simon hatte tagelang immer wieder versucht, es zu umgehen, aber Jean-Louis hatte ihn mehr und mehr mit dunklen Andeutungen darauf hingewiesen, daß es ein Fehler wäre, Enrico zu enttäuschen, der am Erfolg des Hotels doch ein persönliches Interesse hatte [19, p. 350]; 14) disappointment + imaginary unjoy Simon gab sich Mühe, ein enttäuschtes Gesicht zu machen und schüttelte den Kopf, als ob er gerade eine höchst unerfreuli- 
che Nachricht erhalten hätte [19, p. 359]; 15) tension + fear Vor Spannung zitternd, quetschten sie sich in der Ecke zusammen; ein banges Schaudern durchfuhr sie wie eine kalte Brise [19, p. 387]; 16) intense fear + intense rage Sie war zu entsetzt und zu wütend gewesen, um zu weinen, und als er ihr erklärt hatte, daß nichts schiefgehen könne, hatte sie ihn an das letztre Mal erinnert, wo angeblich auch nichts hatte schiefgehen können [19, p. 371]; 17) fear + delight Einer nach dem anderen hievten sie sich durch das Loch und sahen sich tropfend und nervös, doch voll stolzer Begeisterung im Raum um, während Fernand die Tresorfächer mit plastique zu behandeln begann [19, p. 379]; 18) torpor + panic Merkwürdigerweise fühlte er sich ganz ruhig, fast ein wenig fatalistisch, irgendwo zwischen Lähmung und Panik [19, p. 426]; we consider combinations of four emotions to be "non-standard": delight + rage + sorrow + despair Sie hatte die Sache nicht gerade mit Begeisterung aufgenommen, arme alte Mathilde, und hinter ihrer unbeweglichen Miene verbargen sich Wut und Traurigkeit, ha beinahe Verzweiflung [19, p. 371-372].

The above examples are dominated by the emotion of joy that interacts with both positive (surprise, interest), negative (grief, fear, disgust) and indeterminate (unagitation) emotions. In so doing, it "transforms" from the emotion of surprise, the emotion of grief, the emotion of fear, the emotion of disgust, the emotion of unagitation and at the same time serves as an activator of the emotion of surprise, the emotion of grief, the emotion of interest, the emotion of fear. The unfolding of the emotion of joy is conditioned by cognitive, social and mental processes, its "production" of other emotions based on socio-psychological, informational, imaginary-social and cultural factors.

The gradation of the emotion of joy was identified within the semantics of the emotional patterns analyzed above: minimal manifestation war froh, Freude, neutral freudigen, Spaß machen, morphological Lächeln, lächelte, comparative macht mehr Spaß, maximal or intense lachten, sich so sehr freu$t e$. The minimal manifestation of the emotion of joy is traced in the postposition to the emotion of surprise and the emotion of fear, the neutral manifestation is realized in the preposition to the emotion of surprise and in the postposition to the emotion of disgust, the morphological manifestation occurs in the postposition to the emotion of grief and in the preposition to the emotion of interest, the comparative manifestation is marked in the postposition to 
the emotion of unagitation, the maximum manifestation is observed in the preposition to the emotion of grief and the emotion of fear. Therefore, the semantics of the emotion of joy are relatively symmetrical with respect to the semantics of the emotion of surprise, the emotion of fear, the emotion of grief, and asymmetric with respect to the semantics of the emotion of disgust, the emotion of interest, the emotion of unagitation. The symmetry in our research is defined as a mirror reflection of the position of emotion in the structure of the emotional pattern (post- and preposition), the asymmetry is understood as a positional shift (post-, preposition and preposition).

\section{Conclusions}

The results of the research lead to the following general conclusions:

1. The notion of "emotion" comes from the French term, comprises the nature of the inner (spiritual and mental) world of a person, the formation of which correlates with the surrounding and imaginary world, and is differentiated within the national tradition (French, German, American).

2. Emotions and their variants are experienced by both the author and the characters. The sign of an emotion is different: from positive to negative, neutral, indeterminate, imaginary and combined (emotional patterns). Negative and combined emotions and their variants are dominating. Among the negative emotions, the emotion of contempt and the emotion of emptiness are the strongest. The mediators of these emotions are anger as a variant of the emotion of rage and depression as for the emotion of grief. The leading emotion of the emotional pattern is joy. The position of the emotion of joy within the emotional pattern is dual: it precedes another emotion (surprise, interest, grief, fear) or is their consequence (surprise, fear, disgust, grief, unagitation), the semantics is grading: from the minimal value to the neutral, morphological, comparative, maximal one.

3. The emergence of emotions and their variants is determined by the type of subject or communicative situation. The implicit affective situation, the emotional and imaginary ones were revealed. The markers of the affective situation include the affective vocabulary, affective phrases/clichés, diminitives, kinesives, proper names. The emotional situation is characterized by the emotional, stylistically coloured, foreignlanguage (the French language, the English language) vocabulary, as well as affectives, connotatives, occasionalisms, anomalies, shortenings, 
convergence of the synsemantic vocabulary, repetition of words, phrases, sentences. The main feature of the imaginary situation is the use of the subjunctive mood of the verbs scheinen, vermuten and linguistic units mentioned above.

4. The means of realization of emotions and their variants on the lexical level are traditional: a word, a free word-group/a constant collocation, a cliché; compositional speech forms of realization of emotions and their variants are static: speech (monological, dialogical, polylogical) and description (a report on somatic and physiological changes in the human organism). Further studies should investigate emotions in indigenous postmodern fiction.

\section{References:}

1. Izard C.E. (2008). Psikhologiya emotsiy / Per. s angl. K.V. Misnik, A. Tatlybaeva. Sankt-Peterburg: Piter, 464 p.

2. Makhachashvili R.K. (2008). Lingvofilosofski parametry innovatsiy angliyskoi movy v tekhnosferi suchasnogo buttya. Zaporizhzhya: ZNU, 204 p.

3. Myuller V. (2012). Velykyi nimetsko-ukrainskyi slovnyk. Kyiv: Chumatskyi Shlyakh, $792 \mathrm{p}$.

4. Novyi tlumachnyi slovnyk ukrainskoi movy u trekh tomakh (2003) / Uklad. V. Yaremenko, O. Slipushko. Kyiv: Akonit, T. 3: P-YA, 864 p.

5. Pocheptsov G.G. (1990). Yazykovaya mentalnost: sposob predstavleniya mira. Voprosy yazykoznaniya, no. 6, pp. 110-123.

6. Prykhodko A.M. (2002). Skladnosuryadne rechennya v suchasniy nimetskiy movi. Zaporizhzhya: ZDU, 294 p.

7. Psykhologichnyi slovnyk (1982) / za red. V.I. Voytka. Kyiv: Vyscha shkola, 216 p.

8. Redka I. (2017). Forte y piano poezii: vyskhudna y nyzkhidna gradatsii v organizatsii osnovopolozhnykh poetychnykh emotyviv (tryvogy y umyrotvorennya) (na materiali virshiv E. Po). Aktualni problemy romano-germanskoi filologii ta prykladnoi lingvistyky, no. 2(15), pp. 132-135.

9. Romanova N. (2013). Emotyvna leksyka u movi "tvoriv pro tekhniku" Berngarda Kellermanna. Literatyrnyi protses: metodologiya, imena, tradytsii, no. 2 , pp. 26-32.

10. Romanova N.V. (2016). Osobennosti semantiki emotivnoi leksiki v nemetskom yazyke XVII-XX vekov (na materiale poeticheskikh tekstov). Naukovyi visnyk Drogobytskogo derzhavnogo pedagogichnogo universytetu imeni Ivana Franka, Seriya “Filologichni nauky”, Movoznavstvo, T. 2, № 5, pp. 87-91.

11. Romanova N. (2017). Leksychni zasoby verbalizatsii emotsii radosti (na prykladi zbirky kazok "Märchen für Seele". Aktualni problem romano-germanskoi filologii ta prykladnoi lingvistyky, № 2(15), pp. 135-138.

12. Romanova N.V. (2017). Poetychni poglyady germantsiv na svit ta emotsii: semantyko-etymologichne doslidzhennya. Kherson: Ailant, 180 p. 
13. Romanova N.V. (2019). Emotsii u nimetskomovnykh bibliynykh tekstakh Starogo Zapovitu. Kherson: Ailant, 284 p.

14. Strelchenko K.S. (2016). Emotsiogennyi potentsial verbalizovanogo stsenariyu "POZVYAZUVANNYA TAEMNYTSI" (na materiali suchasnoi anglomovnoi prozy). Nova filologiya, vyp. 68, pp. 30-36.

15. Tropina N.P. (2003). Semanticheskaya derivatsiya: multiparadigmalnoe issledovanie. Kherson: KhGU, $336 \mathrm{p}$.

16. Shadskikh Yu.G., Picha V.M. (2008). Psykhologiya: Korotkyi navchalnyi slovnyk: terminy i ponyattya. Lviv: "Magnoliya 2006", 276 p.

17. Shakhovskiy V.I. (2008). Kategorizatsiya emotsiy v leksiko-semanticheskoy sisteme yazyka. Moskva: LKI, 208 p.

18. Sheremeteva G. (2008). Magicheskaya sila tsveta. Sem tsvetov zdorovya. Moskva: Amrita-Rus, 336 p.

19. Mayle P. (2003). Hotel Pastis / Aus dem Englischen von Gockel G., Seuß R., Weiß R. München: Knaur, 464 p.

20. WAHRIG (2012). Wörterbuch der deutschen Sprache / [von R. WahrigBurfeind]. München: dtv, $1152 \mathrm{p}$.

21. Weiterhaus F.-W. (1998). Das neue große Vornamenbuch. München: Wilhelm Goldman Verlag, 397, [3] p. 